\title{
Article
}

\section{Antimelanogenesis Effects of Theasinensin A}

\author{
Hye Yeon Lim ${ }^{1,+}$, Eunji Kim ${ }^{2,+}$, Sang Hee Park ${ }^{1,+}{ }^{-}$, Kyung Hwan Hwang ${ }^{3}$, Donghyun Kim ${ }^{3}$, You-Jung Jung ${ }^{4}$, \\ Spandana Rajendra Kopalli ${ }^{5}$, Yong Deog Hong ${ }^{3}$, Gi-Ho Sung ${ }^{6, *}$ and Jae Youl Cho ${ }^{1,2, *(D)}$
}

1 Department of Biocosmetics, Sungkyunkwan University, Suwon 16419, Korea; gosl177@naver.com (H.Y.L.); 84701@naver.com (S.H.P.)

2 Department of Integrative Biotechnology and Biomedical Institute for Convergence at SKKU (BICS), Sungkyunkwan University, Suwon 16419, Korea; im144069@gmail.com

3 Basic Research \& Innovation Division, R\&D Center, AmorePacific Corporation, Yongin 17074, Korea; khhwang@amorepacific.com (K.H.H.); dhkim417@amorepacific.com (D.K.); hydhong@amorepacific.com (Y.D.H.)

4 Biological Resources Utilization Department, National Institute of Biological Resources, Incheon 22689, Korea; yjjung0@korea.kr

5 Department of Integrative Bioscience and Biotechnology, Sejong University, Seoul 05006, Korea; spandanakopalli@gmail.com

6 Department of Microbiology, Biomedical Institute of Mycological Resource, International St. Mary's Hospital and College of Medicine, Catholic Kwandong University, Simgokro, 100 Gil, 7, Seo-gu, Incheon 22711, Korea

* Correspondence: sung97330@gmail.com (G.-H.S.); jaecho@skku.edu (J.Y.C.); Tel.: +82-32-290-2772 (G.-H.S.); +82-31-290-7868 (J.Y.C.)

+ These authors equally contributed to this work.

check for updates

Citation: Lim, H.Y.; Kim, E.; Park, S.H.; Hwang, K.H.; Kim, D.; Jung, Y.-J.; Kopalli, S.R.; Hong, Y.D.; Sung, G.-H.; Cho, J.Y. Antimelanogenesis Effects of Theasinensin A. Int. J. Mol. Sci. 2021, 22, 7453. https://doi.org/ $10.3390 /$ ijms 22147453

Academic Editor: William N. Setzer

Received: 9 June 2021

Accepted: 7 July 2021

Published: 12 July 2021

Publisher's Note: MDPI stays neutral with regard to jurisdictional claims in published maps and institutional affiliations.

Copyright: (c) 2021 by the authors. Licensee MDPI, Basel, Switzerland. This article is an open access article distributed under the terms and conditions of the Creative Commons Attribution (CC BY) license (https:/ / creativecommons.org/licenses/by/ $4.0 /)$.

\begin{abstract}
Theasinensin A (TSA) is a major group of catechin dimers mainly found in oolong tea and black tea. This compound is also manufactured with epigallocatechin gallate (EGCG) as a substrate and is refined after the enzyme reaction. In previous studies, TSA has been reported to be effective against inflammation. However, the effect of these substances on skin melanin formation remains unknown. In this study, we unraveled the role of TSA in melanogenesis using mouse melanoma B16F10 cells and normal human epidermal melanocytes (NHEMs) through reverse transcription polymerase chain reaction (RT-PCR), Western blotting analysis, luciferase reporter assay, and enzyme-linked immunosorbent assay analysis. TSA inhibited melanin formation and secretion in $\alpha$-melanocyte stimulating hormone ( $\alpha$-MSH)-induced B16F10 cells and NHEMs. TSA down-regulated the mRNA expression of tyrosinase (Tyr), tyrosinase-related protein 1 (Tyrp1), and Tyrp2, which are all related to melanin formation in these cells. TSA was able to suppress the activities of certain proteins in the melanocortin 1 receptor (MC1R) signaling pathway associated with melanin synthesis in B16F10 cells: cyclic adenosine monophosphate (cAMP) response element-binding protein (CREB), protein kinase A (PKA), tyrosinase, and microphthalmia-associated transcription factor (MITF). We also confirmed $\alpha$-MSH-mediated CREB activities through a luciferase reporter assay, and that the quantities of CAMP were reduced by TSA in the enzyme linked immunosorbent assay (ELISA) results. Based on these findings, TSA should be considered an effective inhibitor of hyperpigmentation.
\end{abstract}

Keywords: theasinensin A; melanogenesis; MC1R; cAMP; CREB

\section{Introduction}

The skin is the largest tissue consisting of multiple epithelial tissues that protect muscles and organs, according to the definition of animal anatomy and dermatology [1]. The skin is a very important organization that protects the body from pathogens and maintains constancy [2] of insulation, body temperature control, sensory functions, the synthesis of vitamins, and the protection of vitamin B folate [3]. The skin is composed of the epidermis, dermis, and subcutaneous layers. Among them, the epidermis is the outermost layer that consists of exfoliating cells, Langerhans cells, and melanin-forming cells [4,5]. Between the 
epidermis and dermis, melanocytes are evenly distributed in the layers of keratinocytes [6]. When the skin is exposed to UV light, keratinocytes produce $\alpha$-melanocyte stimulating hormone $(\alpha-\mathrm{MSH})$, which induces the melanocortin 1 receptor (MC1R) signaling pathway in melanocytes [7]. The activation of the MC1R signaling pathway by $\alpha$-MSH leads to the activation of the cyclic adenosine monophosphate (cAMP) signaling pathway, which is mainly associated with pigment production [8,9]. In sequence, activated microphthalmiaassociated transcription factor (MITF) transcribes melanin synthesis-related genes: Mitf itself, Tyrp1, Tyrp2, and Tyr [10-12]. Moreover, MITF is essential for melanin formation, the development of melanin-producing cells, and long-term cell survival [13]. Tyrosine is a substrate that is converted into L-Dopaquinone by tyrosinase. L-Dopaquinone then produces dark-brown and red melanin by automatic oxidation and enzyme reactions [11,14]. Formed pigment or melanin protects the skin from UV irradiation by absorbing some of the irradiation $[15,16]$. Melanin-forming cells also contain DNA-repairing enzymes that restore UV damage; skin cancer is more likely to develop if there is a deficiency in these enzymes $[17,18]$. Direct exposure to UV light could be a health risk. Acute exposure to UV light causes sunburn or local immunosuppression; however, these are reversible $[19,20]$. The effects of chronic UV irradiation include vascular damage, atrophy, and fibrosis, and can cause various diseases such as skin cancer, skin lesions, and actinic keratosis [20-23]. A melanoma is a malignant tumor of melanocytes that produces melanin pigments. It can occur anywhere in the region where melanocytes exist, most often on the skin, and continuously produces melanin [24].

Theasinensin A (TSA) (Figure 1) is a polyphenol flavonoid created during fermentation through the oxidation of epigallocatechin gallate and is a bioactive compound in oolong tea [25-27]. In previous studies, mitogen-activated protein kinase kinase (MAPKK) and extracellular signal-regulated kinase (ERK) have been suggested as potential targets for TSA to inhibit inflammatory signaling [28,29], but there have been no reports on the effects of TSA on the creation of melanin on the skin. Therefore, the purpose of this study was to demonstrate the mechanisms of TSA in the inhibition of melanin formation.

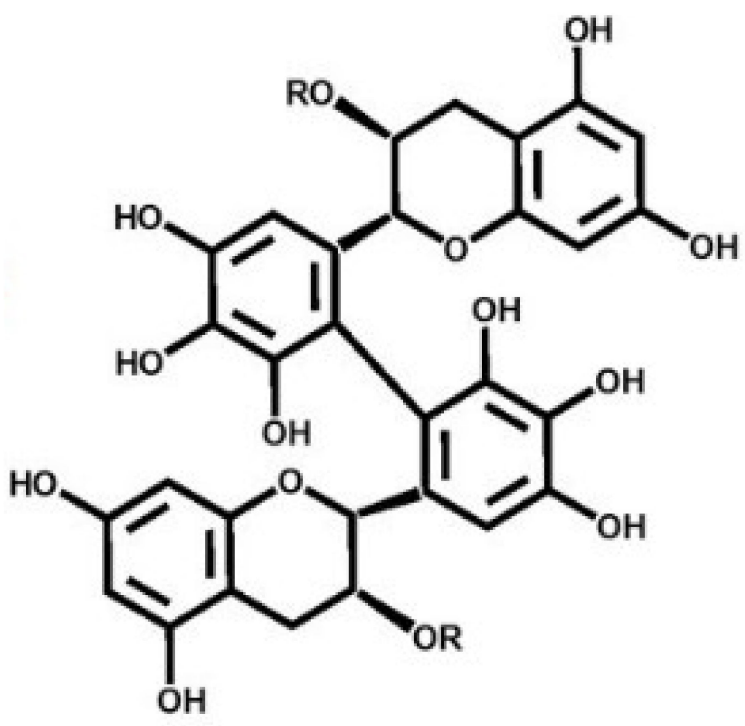

Figure 1. Structure of theasinensin A (TSA). TSA was synthesized by the enzymatic reaction of epigallocatechin gallate (EGCG).

In this study, we examined the effects of TSA on melanogenesis using B16F10 murine melanoma cells. Our research revealed that TSA regulates the cyclic adenosine monophosphate (cAMP) element binding (CREB) signaling pathway. 


\section{Results}

2.1. Effect of Theasinensin A on Melanin Produced by B16F10 Melanoma Cells and Human Epidermal Melanocytes

We explored the role of TSA in melanin production in both B16F10 melanoma cells and normal human epidermal melanocytes (NHEMs). Firstly, we assessed the cytotoxic dose of TSA with an MTT assay and determined that TSA did not exhibit cell toxicity in the concentration range of $6.25-25 \mu \mathrm{M}$ for B16F10 cells, or 12.5-50 M for NHEMs for $48 \mathrm{~h}$ (Figure $2 \mathrm{a}, \mathrm{b}$ ). Tyrosinase is an important molecule in the melanogenesis process and consists of a copper-containing enzyme that is present in plant and animal tissues and catalyzes the production of melanin and other pigments from tyrosine by oxidation [30,31]. Therefore, we investigated the tyrosinase inhibitory activity of TSA using mushroom tyrosinase and L-3,4-dihydroxyphenylalanine (L-DOPA); mushroom tyrosinase activity was inhibited by TSA. This result indicates that TSA indeed affects tyrosinase activity (Figure 2c). To confirm the effects of TSA on melanin secretion and content in B16F10 cells and NHEMs, we treated TSA or arbutin as a positive control with $\alpha-\mathrm{MSH}$, a melanocytestimulate hormone, to induce melanogenesis. The melanin-secreted levels from both B16F10 melanoma cells and NHEMs were significantly inhibited by TSA $(12.5-25 \mu \mathrm{M})$, and the production of intracellular melanin contents was suppressed in a dose-dependent manner (Figure 2d-f).

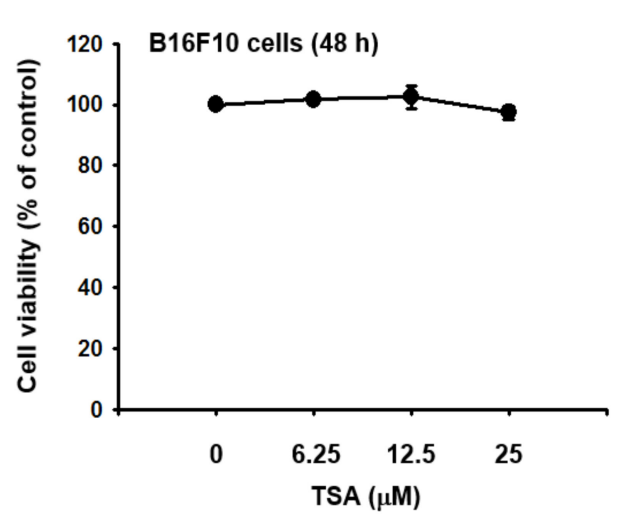

(a)

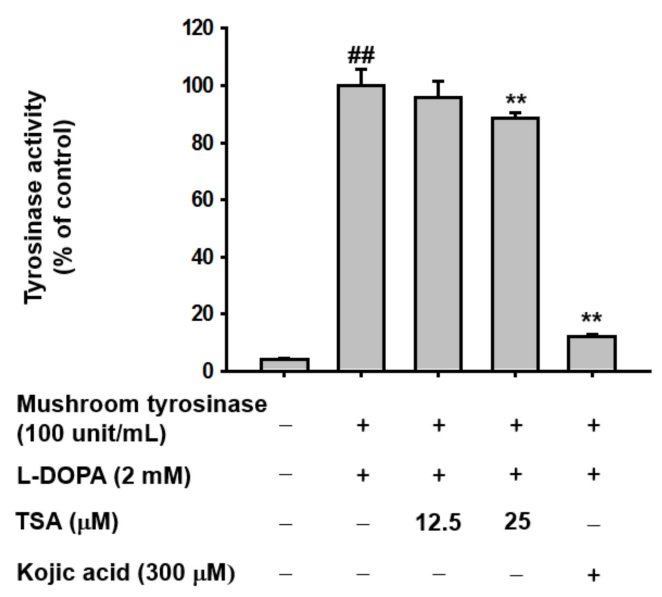

(c)

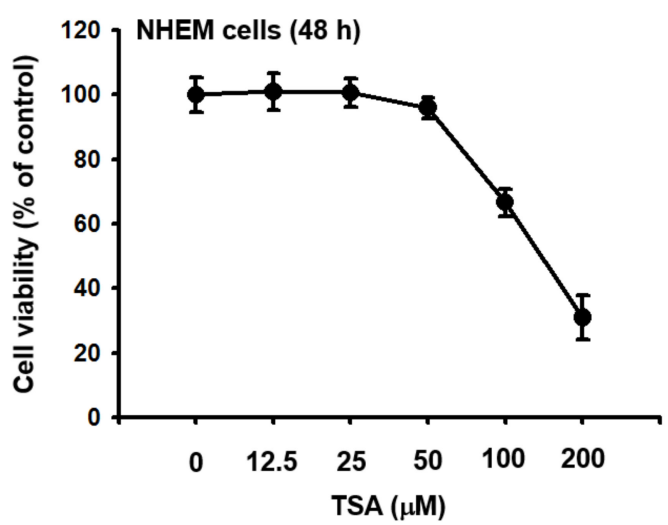

(b)

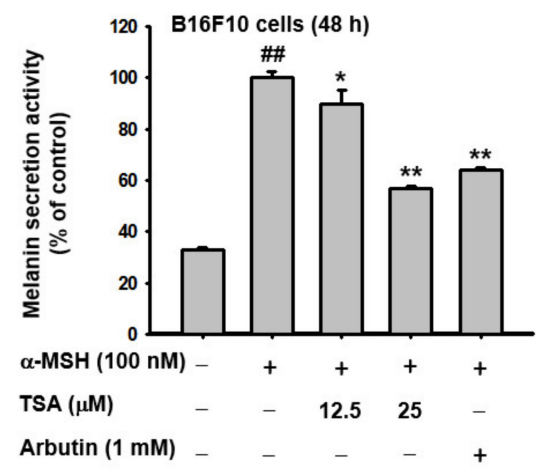

(d)

Figure 2. Cont. 


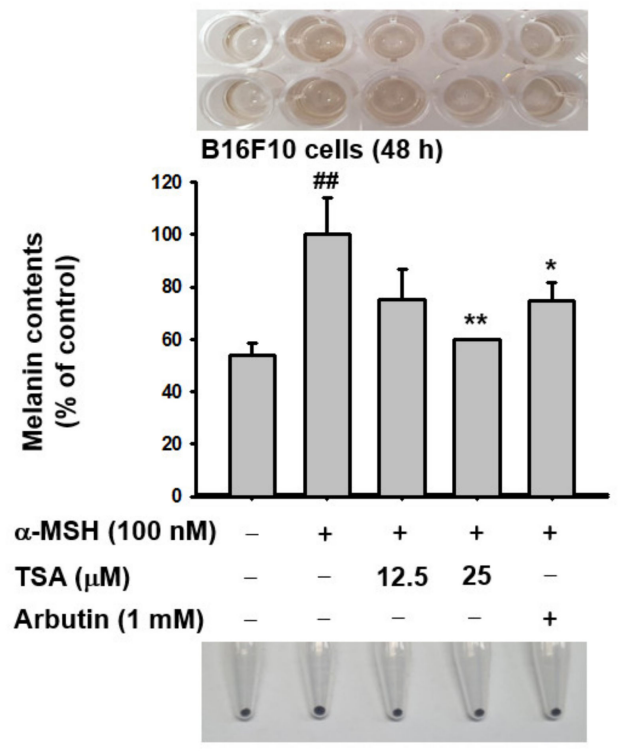

(e)

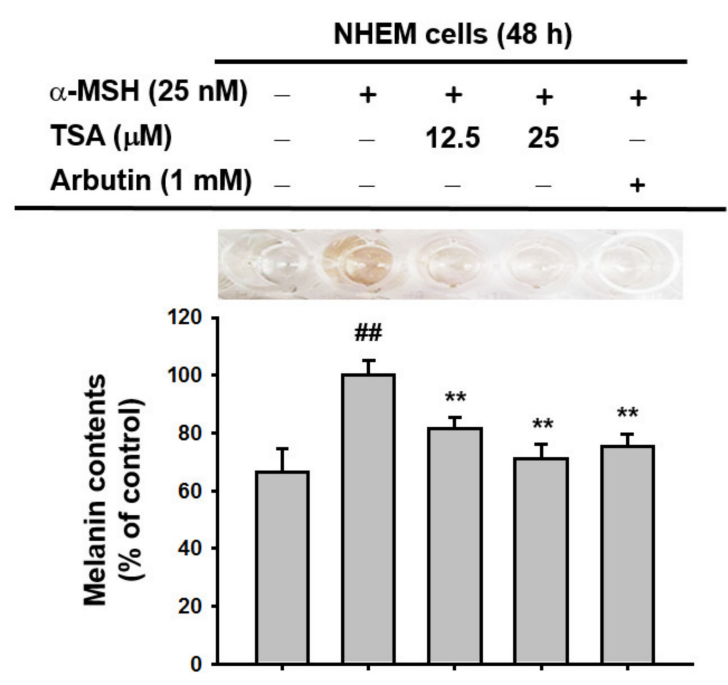

(f)

Figure 2. The antimelanogenesis effect of TSA in murine melanoma cells (B16F10). (a,b) B16F10 cells and NHEMs were treated with TSA $(6.25-200 \mu \mathrm{M})$ for $48 \mathrm{~h}$, and cell viability was analyzed using MTT assay $(n=5$ from 3 independent experiments). (c) Mushroom tyrosinase was reacted with TSA $(6.25-25 \mu \mathrm{M})$ or kojic acid $(300 \mu \mathrm{M})$, and L-DOPA was added. Tyrosinase activity was analyzed by measuring absorbance at $475 \mathrm{~nm}(n=4$ from 3 replicates). (d-f) B16F10 cells and MHEMs were treated with TSA $(12.5-25 \mu \mathrm{M})$ or arbutin $(1 \mathrm{mM})$ for $48 \mathrm{~h}$. Cell-cultured media were collected for melanin secretions by measuring absorbance at $470 \mathrm{~nm}(n=4$ from 3 independent experiments). The intracellular melanin contents were determined by measuring optical density at $450 \mathrm{~nm}$ with 3 replications. +: indicates treatment, - : indicates non-treatment. For all applicable experiments, statistical significance was evaluated using the Mann-Whitney U test. \#\# $p<0.01$ compared with the normal group, ${ }^{*} p<0.05$ compared with the control group, ${ }^{* *} p<0.01$ compared with the control group.

\subsection{Effect of TSA on the Expression of Genes Related to Melanogenesis}

To investigate which melanogenesis-related genes were regulated by TSA, B16F10 cells and NHEMs were treated with TSA or arbutin with $\alpha-\mathrm{MSH}$ in order to induce mRNA expression. The treatment of B16F10 cells and NMEMs with TSA reduced the mRNA expression levels of Tyr, Tyrp1, and Tyrp2 (Figure 3a-d). Additionally, increased protein levels of tyrosinase and MITF during $\alpha$-MSH exposure were also inhibited by TSA (Figure 3e). These outcomes supported previous results that showed a reduction in melanin synthesis via TSA.

\subsection{Effect of TSA on the cAMP/CREB Signaling Pathway through Regulation of Melanogenesis \\ In order to dissect the molecular mechanism of TSA underlying melanogenesis, we subsequently examined the cAMP signaling pathway by Western blotting analysis. TSA inhibited phosphorylation of CREB and PKA (Figure 4a), but there was no alteration in MAPK signaling (Figure $4 \mathrm{~b}$ ). The suppressive patterns of p-PKA and p-CREB levels were also seen from earlier time points (from $5 \mathrm{~min}$ to $24 \mathrm{~h}$ ), as shown in Figure 4c. Synthetically, it is suggested that TSA exhibits antimelanogenesis effects through the regulation of the cAMP signaling pathway, but not the AP-1 signaling pathway.}




\begin{tabular}{|c|c|c|c|c|}
\hline \multirow{3}{*}{$\begin{array}{l}\alpha-M S H(100 \mathrm{nM}) \\
\text { TSA }(\mu \mathrm{M})\end{array}$} & \multicolumn{4}{|c|}{ B16F10 cells (12 h) } \\
\hline & ) - & + & + & + \\
\hline & - & 12.5 & 25 & - \\
\hline Arbutin (1 mM) & - & - & - & + \\
\hline Tyrosinase & $\longrightarrow-$ & - & - & - \\
\hline TYRP-1 & $\ldots$ & 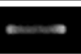 & 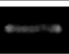 & 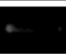 \\
\hline TYRP-2 & 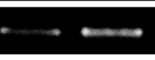 & $\ldots$ & 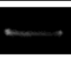 & \\
\hline GAPDH & & & & \\
\hline
\end{tabular}

(a)

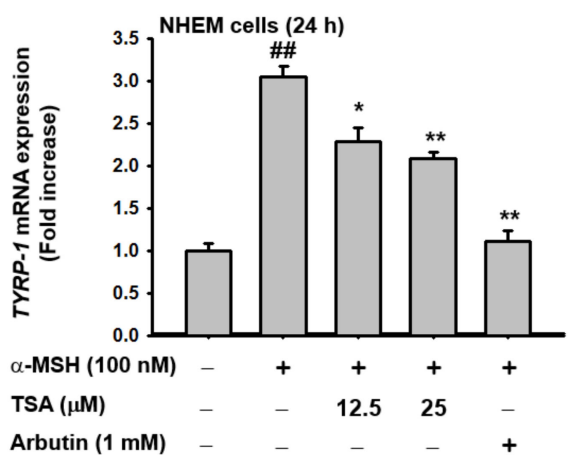

(c)

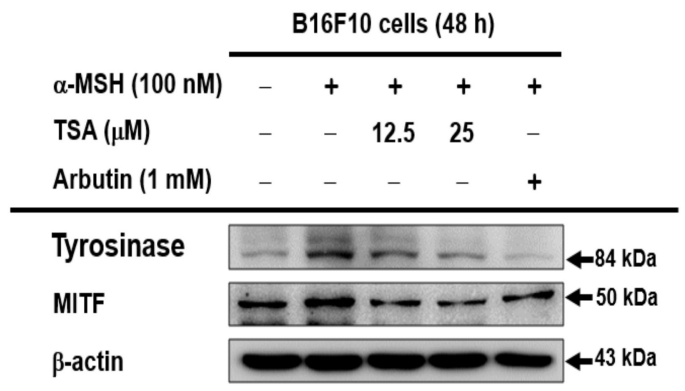

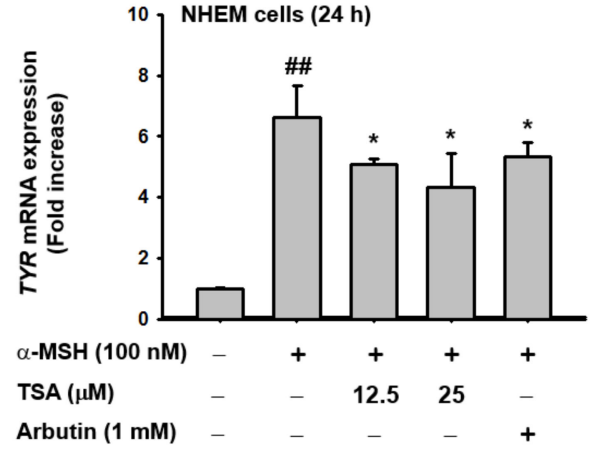

(b)

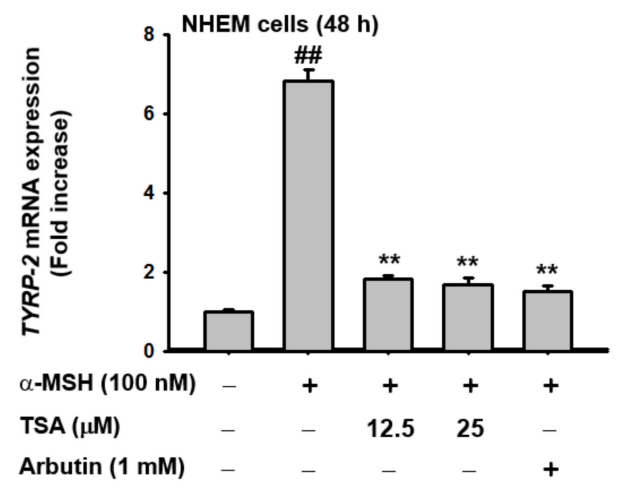

(d)

(e)

Figure 3. The effect on transcriptional events of melanogenesis. (a-d) The mRNA expression of Tyr, Tyrp1, and Tyrp2 in B16F10 or NHEMs treated with TSA $(12.5-25 \mu \mathrm{M})$ or arbutin $(1 \mathrm{mM})$ in response to $\alpha$-MSH for 24 or 48 h were determined using RT-PCR and real-time PCR analyses. (e) Protein levels of tyrosinase and MITF in TSA (12.5-25 $\mu$ M)- or arbutin $(1 \mathrm{mM})$-treated B16F10 cells, in response to $\alpha-\mathrm{MSH}$ for $48 \mathrm{~h}$ of TSA, were determined using Western blotting analysis. For all applicable experiments, statistical significance was evaluated using the Mann-Whitney U test. All experiments were performed at least three times. +: indicates treatment, - : indicates non-treatment. \#\# $p<0.01$ compared with the normal group, ${ }^{*} p<0.05$ and ${ }^{* *} p<0.01$ compared with the control group. 


\begin{tabular}{|c|c|c|c|c|c|}
\hline \multirow[b]{2}{*}{$\alpha-M S H(100 \mathrm{nM})$} & \multicolumn{5}{|c|}{ B16F10 cells (48 h) } \\
\hline & - & + & + & + & + \\
\hline $\mathrm{TSA}(\mu \mathrm{M})$ & - & - & 12.5 & 25 & - \\
\hline Arbutin (1 mM) & - & - & - & - & + \\
\hline p-PKA & - & - & $=$ & $=$ & $=$ \\
\hline PKA & & & & 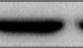 & \\
\hline p-CREB & es & $8=$ & - & 20 & \\
\hline CREB & & & & $=$ & $=$ \\
\hline$\beta$-actin & & & & & \\
\hline
\end{tabular}

(a)

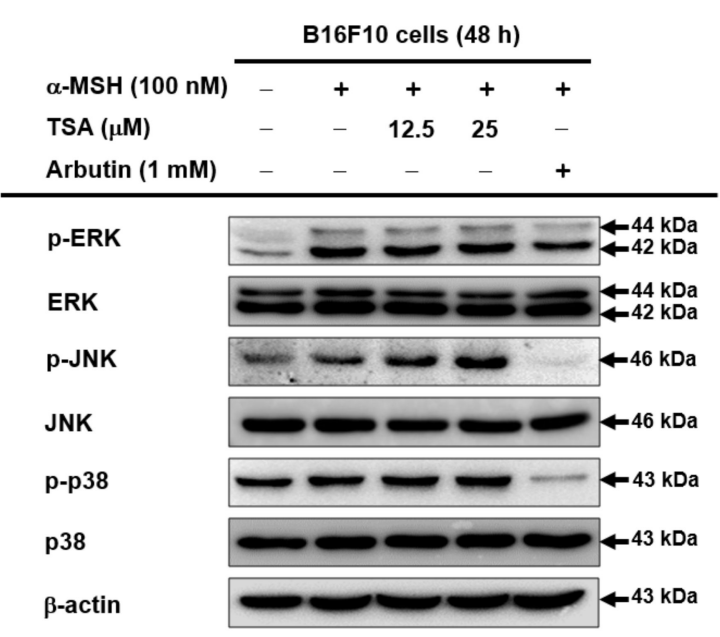

(b)

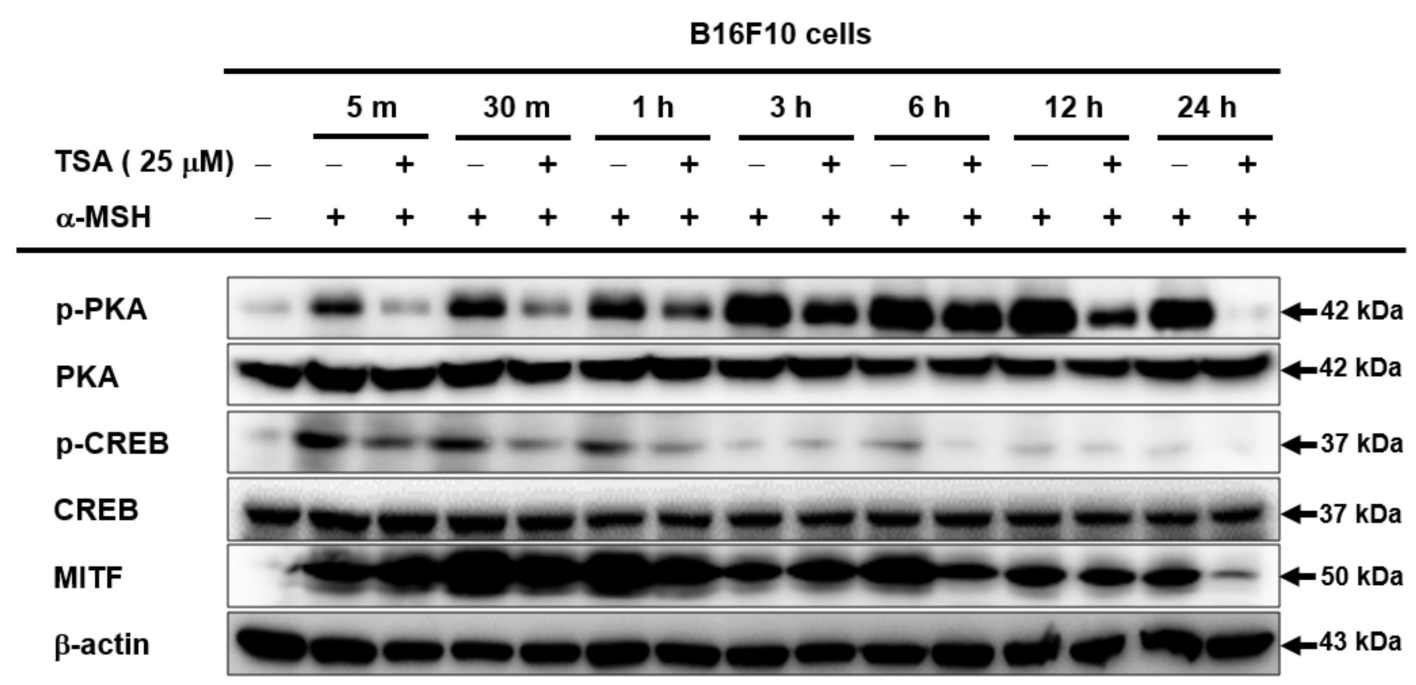

(c)

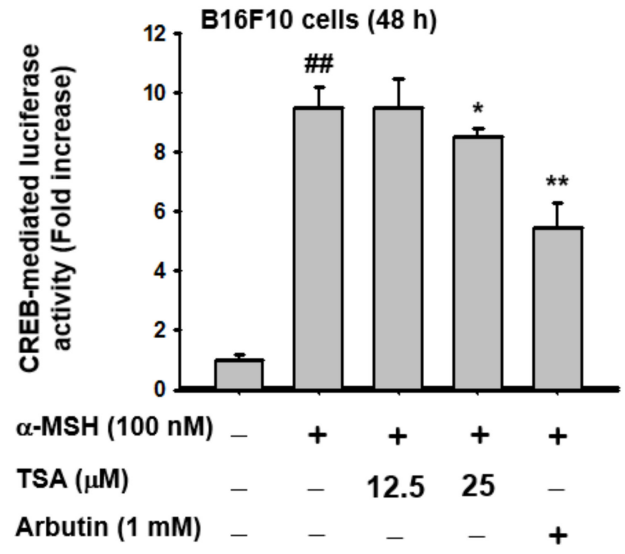

(d)

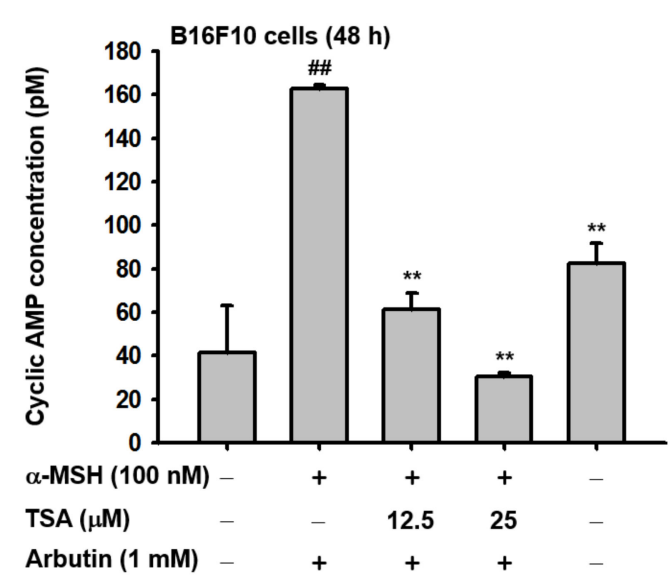

(e)

Figure 4. Regulation of the cAMP/CREB signaling pathway of TSA in B16F10 cells. (a-c) Protein levels of various cyclic 
adenosine monophosphate (cAMP) signaling proteins and MAPK signaling proteins in B16F10 cells pretreated with TSA $(12.5-25 \mu \mathrm{M})$ or arbutin $(1 \mathrm{mM})$ in response to $\alpha-\mathrm{MSH}$ at indicated time points were determined using Western blotting analysis. (d) Activation of CREB in B16F10 cells treated with TSA $(12.5-25 \mu \mathrm{M})$ or arbutin $(1 \mathrm{mM})$ was determined using the CREB-mediated luciferase system $(n=4$ with three experimental replicates). (e) Levels of cAMP in B16F10 cells treated with TSA $(12.5-25 \mu \mathrm{M})$ or arbutin $(1 \mathrm{mM})$ were measured using an ELISA assay $(n=4)$. For all applicable experiments, statistical significance was evaluated using the Mann-Whitney U test. \#\# $p<0.01$ compared with the normal group, ${ }^{*} p<0.05$ and ** $p<0.01$ compared with the control group.

We further confirmed the antimelanogenic effect of TSA by regulating the cAMP/CREB signaling pathway in B16F10 melanoma cells. To measure CREB transcriptional activity, we conducted a CREB-mediated luciferase assay in B16F10 cells, as reported previously [32]. TSA at $25 \mu \mathrm{M}$ significantly decreased CREB-mediated luciferase activity in B16F10 cells (Figure 4d). Moreover, we measured the expression level of cAMP in cells by ELISA analysis because CREB activation relies on CAMP synthesis [33]. It was confirmed that TSA decreased the concentration of cAMP in B16F10 cells in a dose-dependent manner (Figure 4e).

\section{Discussion}

In this study, we determined the antimelanogenesis effect of TSA in B16F10 murine melanoma cells and NHEMs stimulated by $\alpha$-MSH at non-toxic concentrations $(0,6.25$, and $12.5 \mu \mathrm{M})$. We stimulated B16F10 cells and NHEMs with $\alpha-\mathrm{MSH}$, which activated various transcription factors and enzymes to induce melanin production [34]. TSA inhibited melanogenesis through the cAMP/CREB signaling pathway (Figures $2 \mathrm{~d}-\mathrm{f}$ and $4 \mathrm{~d}, \mathrm{e}$ ). TSA downgraded the mRNA of Tyr, Tyrp1, and Tyrp2, which are important genes in the process of melanin production in DOPA chrome (Figure 3a-d). The antimelanogenesis activities of TSA in B16F10 murine melanoma cells and NHEMs are summarized in Figure 5.

Melanogenesis is a process involving the catalysis of tyrosine by tyrosinase, TYRP1, TYRP2/dopachrome tautomerase (DCT), and MITF. Tyrosine is involved in the formation of melanin as a substrate of tyrosine. Phosphoric acidification of MITF increases the tyrosinase enzyme, an enzyme that oxidizes tyrosine into DOPA, through DOPA as a substrate, and into DOPA quinone [35]. These results indicate that TSA regulates melanin secretion and intracellular melanin content in B16F10 cells by inhibiting the cAMP pathway. Tyrosinases are mediated in this process, and it is thought that the suppression of tyrosinase activity is an effective strategy for the suppression of melanin formation $[1,36]$.

MAPKs consisting of ERK, JNK, and p38 are important adjuncts to melanin formation. MAPKs induce the phosphoric acidification of MITF [37], and MITF expression is activated through c-Kit/MAPK signaling [38]. The expression of MITF and tyrosinase is triggered by p38/MAPK and is related to CREB activity [39,40]. In contrast, the ERK protein induces the degradation of MITF, while p38 blocks melanogenesis by degrading tyrosinase [41-44]. MAPK proteins exhibit conflicting effects on melanogenesis, but are considered as anti-melanogenic targets in several studies. Several anti-melanogenic substances from natural products such as beauvericin, maclurin, and dihydromyricetin have inhibited both PKA and MAPK activation $[40,45,46]$. However, in this study, TSA reduced PKA/CREB signaling and not MAPK signaling, implying a different mode of action due to a different chemical structure. The ethanolic extract of Melia azedarach L. solely affects the CAMP/PKA/CREB pathway in melanogenesis, while resorcinol from argan oil has an antimelanogenic effect by suppressing cAMP signaling instead of MAPKs [41,47], implying that structurally similar compounds could be included in these extracts. Hence, natural substances seem to have diverse regulatory mechanisms that affect melanogenesis based on their structural features. 


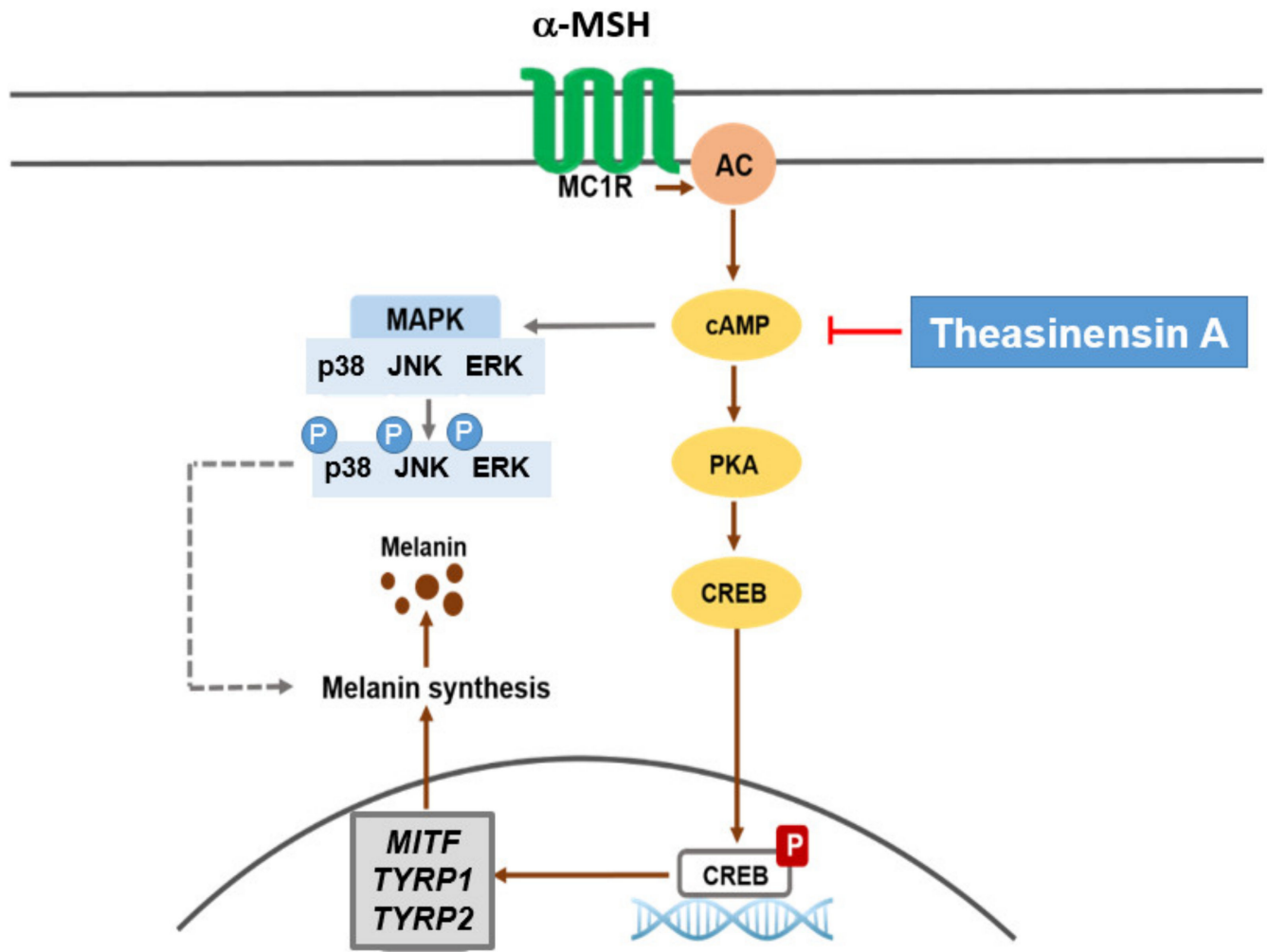

Figure 5. Mechanism of melanogenesis regulated by TSA. Treatment with TSA suppressed melanin Figure 1. and Tyrp2 through the downregulation of the cAMP pathway in $\alpha$-MSH-treated B16F10 cells and NHEMs. $\alpha$-MSH: $\alpha$-melanocyte stimulating hormone, MC1R: melanocortin 1 receptor, AC: adenylyl cyclase, cAMP: cyclic adenosine monophosphate, PKA: protein kinase A, CREB: cAMP response element-binding protein, MAPK: mitogen-activated protein kinase, JNK: c-Jun-N-terminal kinase, ERK: extracellular signal-regulated kinase, MITF: microphthalmia-associated transcription factor, TRRP1: tyrosinase-related protein 1, and TYRP2: tyrosinase-related protein 1. Arrows indicate positive signal. Lines with theasinensin A indicate inhibitory signal.

The MC1R signaling pathway is an important signaling route for melanin formation [48]. Downstream $\alpha$-MSH-induced MC1R activation leads to the stimulation of adenylyl cyclase (AC) and the production of cAMP, which activates PKA and intracellular CREB proteins [49]. CREB was activated through phosphorylation and induced the expression of MITF [50]. In addition, MITF was modulated by the phosphoinositide 3-kinase/protein kinase B (PI3K/PKB (AKT)) pathway in $\alpha$-MSH-stimulated MC1R signaling. The activation of PKB suppresses melanogenesis by downregulating MITF transcription [33,51]. Several compounds were investigated for the role of melanogenesis in the formation of the PI3K/PKB pathway. Hydroxyectonie modulated melanogenesis by the activation of PKB and p38 [52]. The anti-melanogenic effect of a caffeamide derivate was elucidated, and phosphorylated PKB was increased [53]. In this study, the activation of PKB was not examined. However, since cAMP/PKA inhibited PI3K/PKB activity to induce melanogenesis [53,54], there is a possibility that TSA regulates PKB activity based on our results (Figure $4 \mathrm{a}, \mathrm{c}-\mathrm{e}$ ). An investigation of the regulatory mechanisms of TSA on $\alpha$-MSH-stimulated MC1R/PKB signaling would be meaningful for further study.

UV light can cause various skin diseases and abnormalities such as skin cancer, rashes, wrinkling, and skin pigmentation [55]. Melanin induction under UV irradiation is a type of protective mechanism for the skin to avoid burning, irritations as well as the generation of skin cancer [56]. From this view, anti-pigmentation strategies as cosmetics may increase the risk of skin cancer. Therefore, it seems to be very important to check whether an anti-melanogenic compound increases skin cancer risk or not. Since we are also hoping to develop an anti-pigmentation cosmeceutical with TSA, we tested its potential risk for skin 
cancer. For this, the protective activity of TSA on UV-induced DNA damage and mutation, a major cause of skin cancer [57], was finally examined. To do this, we employed a bacterial reverse mutation test (Ames test), as reported previously [58]. As Figure S1 shows, TSA reduced the colony formation of Salmonella typhimurium upregulated by UVB irradiation at $25 \mu \mathrm{M}$, implying that TSA can block UVB-induced DNA mutation. This result strongly suggests that TSA can block DNA damage during UV exposure, which can be beneficial, leading to the reduction of skin cancer risk.

\section{Materials and Methods}

\subsection{Materials}

B16F10 cells were purchased from American Type Culture Collection (Rockville, MD, USA). Normal human epidermal melanocytes (NHEMs) and melanocyte growth medium $\mathrm{m} 2$ (c24305) were purchased from the Promocell (Heidelberg, Germany). We purchased 3-(4-5-Dimethylthiazol-2-yl)-2,5-diphenyltetrazolium bromide (MTT) from Amresco (Brisbane, Australia). Theasinensin A (TSA) was supplied from Amorepacific Co. (Seoul, Korea). Dulbecco's Modified Eagle's medium (DMEM), fetal bovine serum (FBS), phosphatebuffered saline (PBS), streptomycin, penicillin, and L-glutamine were purchased from Gibco (Grand Island, NY, USA). Sodium dodecyl sulfate (SDS), L-3,4-dihydroxyphenylalanine (L-DOPA), 5-hydroxy-2-hydroxymethyl-4H-pyranone (kojic acid), 4-hydroxyphenyl- $\beta$-Dglucopyranoside (arbutin), and a-melanocyte stimulating hormone $(\alpha-\mathrm{MSH})$ were obtained from Sigma Chemical Co. (St. Louis, MO, USA). TRIzol reagent was supplied by Molecular Research Center Inc. (Cincinnati, OH, USA). MuLV reverse transcriptase was purchased from Thermo Fisher Scientific (Waltham, MA, USA). Primers specific for TYR, TYRP1, $T Y R P 2$, and GAPDH for the reverse transcriptase polymerase chain reaction (RT-PCR) were obtained from Bioneer Inc. (Daejeon, Korea). Specific antibodies for total-forms and phospho-forms of tyrosinase, MITF, CREB, PKA, ERK, JNK, p-p38, and $\beta$-actin were purchased from Cell Signaling Technology (Beverly, MA, USA) or Santa Cruz Biotechnology (Santa Cruz, CA, USA). Enhanced chemiluminescence reagents were obtained from $\mathrm{Ab}$ Frontier (Seoul, Korea). The luciferase assay system was purchased from Promega (Madison, WI, USA). Cyclic AMP Elisa was purchased from Abcam (Cambridge, UK).

\subsection{Compound Preparation and Treatment}

A stock solution of TSA was prepared by dilution in $25 \mathrm{mM}$ of DMSO. TSA was dissolved in 100\% dimethylsulfoxide (DMSO) and then further diluted in the culture medium to prepare the indicated concentrations. Equal amounts of DMSO $(0.2 \mu \mathrm{L}$ DMSO $/ 200 \mu \mathrm{L}$ medium) were always prepared for the corresponding normal or control groups as a vehicle control.

\subsection{Cell Culture}

B16F10, the murine melanoma cell line, was cultured in DMEM supplemented with $10 \% \mathrm{FBS}$ and $1 \%$ streptomycin $(100 \mathrm{mg} / \mathrm{mL})$ and penicillin $(100 \mathrm{U} / \mathrm{mL})$ at $37^{\circ} \mathrm{C}$ in a $5 \%$ $\mathrm{CO}_{2}$ humidified incubator. NHEM cells were cultured in $\mathrm{M} 2$ media supplemented with $1 \%$ penicillin-streptomycin in a $5 \% \mathrm{CO}_{2}$ incubator at $37^{\circ} \mathrm{C}$.

\subsection{MTT Assay}

In order to determine the non-cytotoxic concentration of TSA in melanocytes, we employed the MTT assay. Since NHME is a normal human fibroblast, a wide range of concentrations of TSA were used to treat the NHMEs. B16F10 cells or NHEM cells $\left(5 \times 10^{4}\right.$ cells $\left./ \mathrm{mL}\right)$ were seeded onto a 96 -well plate. Cells were incubated in TSA $(6.25-100 \mu \mathrm{M})$ for $48 \mathrm{~h}$. A conventional MTT assay was conducted, and absorbance at $570 \mathrm{~nm}$ was measured by a Spectra Max 250 microplate reader, as previously described [59]. 


\subsection{Tyrosinase Activity Assay}

TSA $(12.5-25 \mu \mathrm{M})$ or kojic acid $(300 \mu \mathrm{M})$ and mushroom tyrosinase (100 unit/mL) were incubated for $30 \mathrm{~min}$ in a $5 \% \mathrm{CO}_{2}$ humidified incubator and treated with L-DOPA $(40 \mu \mathrm{g} / \mathrm{mL})$ for $5 \mathrm{~min}$ on a 96-well plate. Tyrosinase activity was measured using the absorbance of mixture at $475 \mathrm{~nm}$ by a Spectra Max 250 microplate reader. Tyrosinase activity assay was conducted, as previously described [60].

\subsection{Melanin Secretion and Content Assay}

B16F10 cells $\left(0.5 \times 10^{5}\right.$ cells $/$ well $)$ or NHEM cells $\left(2 \times 10^{5}\right.$ cells $\left./ \mathrm{mL}\right)$ were seeded into a 12-well plate and incubated for $24 \mathrm{~h}$. The culture media were replaced with new, fresh media containing TSA $(12.5-25 \mu \mathrm{M})$ and arbutin $(1 \mathrm{mM})$. The $\alpha$-MSH $(100 \mathrm{nM})$ was subsequently used to stimulate the cells for $48 \mathrm{~h}$. Afterwards, the secreted culture medium was measured by absorbance at $475 \mathrm{~nm}$ using a Spectra Max 250 microplate reader. Harvested cells were lysed by lysis buffer (50 mM Tris HCL pH 7.5, $20 \mathrm{mM} \beta-$ glycerophosphate $\mathrm{pH} 7.5,120 \mathrm{mM} \mathrm{NaCl}$, and $2 \% \mathrm{NP}-40$ ) and centrifuged at 10,000 $\times g$ for $3 \mathrm{~min}$. Concentrated cell pellets were resuspended in 10\% DMSO in $1 \mathrm{~N} \mathrm{NaOH}$ and incubated in a heating block for $10 \mathrm{~min}$ at $60^{\circ} \mathrm{C}$. The melanin contents were measured at an absorbance of $405 \mathrm{~nm}$ using a Spectra Max 250 microplate reader. A melanin secretion and contents assay was conducted, as previously described [60].

\subsection{Reverse Transcription Polymerase Chain Reaction (RT-PCR) and Real-Time PCR}

To confirm the expression of mRNA related to melanogenesis, B16F10 cells and NHEMs $\left(4 \times 10^{5}\right.$ cells) were treated with TSA $(12.5-25 \mu \mathrm{M})$ or arbutin $(1 \mathrm{mM})$ with $\alpha$ MSH as a positive control to stimulate melanogenesis for $12 \mathrm{~h}$. Total RNA was extracted using a TRIzol reagent. cDNA was synthesized from total RNA $(1 \mu \mathrm{g})$ using MuLV reverse transcriptase, which was produced according to the instructions of the manufacturer. RT-PCR and real-time PCR analyses were conducted, as previously described, with modification [60,61]. Primer sequences used in this study are listed in Table 1.

Table 1. Sequences of primers (mouse) used in RT-PCR.

\begin{tabular}{|c|c|c|c|}
\hline Name & Direction & Sequence $\left(5^{\prime}\right.$ to $\left.3^{\prime}\right)$ & Anneal Temp. $\left({ }^{\circ} \mathrm{C}\right)$ \\
\hline \multicolumn{4}{|l|}{ Mouse } \\
\hline \multirow{2}{*}{ Tyr } & Forward & GTCCACTCACAGGGATAGCAG & 56 \\
\hline & Reverse & AGAGTCTCTGTTATGGCCGA & \\
\hline \multirow{2}{*}{ Tyrp1 } & Forward & ATGGAACGGGAGGACAAACC & \\
\hline & Reverse & TCCTGACCTGGCCATTGAAC & 57 \\
\hline \multirow{2}{*}{ Tyrp2 } & Forward & CAGTTTCCCCGAGTCTGCAT & \\
\hline & Reverse & GTCTAAGGCGCCCAAGAACT & 58 \\
\hline \multirow{2}{*}{ Gapdh } & Forward & ACCACAGTCCATGCCATCAC & \\
\hline & Reverse & CСACCACCCTGTTGCTGTAG & 58 \\
\hline \multicolumn{4}{|l|}{ Human } \\
\hline \multirow{2}{*}{ Tyr } & Forward & AACAAGCGAGTCGGATCTGG & 58 \\
\hline & Reverse & GACGACACAGCAAGCTCACA & 58 \\
\hline \multirow{2}{*}{ Tyrp1 } & Forward & GTGCCACTGTTGAGGCTTTG & \\
\hline & Reverse & ATGGGGATACTGAGGGCTGT & 58 \\
\hline \multirow{2}{*}{ Tyrp2 } & Forward & CTGGCCCCTATTGGTCACAA & \\
\hline & Reverse & TGGCAGATCGATGGCATAGC & 58 \\
\hline \multirow{2}{*}{ Gapdh } & Forward & TCAAGGCTGAGAACGGGAAG & \\
\hline & Reverse & TCGCCCCACTTGATTTTGGA & 57 \\
\hline
\end{tabular}

\subsection{Preparation of Total Cell and Lysates}

B16F10 cells were treated with TSA $(12.5-25 \mu \mathrm{M})$ or arbutin $(1 \mathrm{mM})$ with $\mu-\mathrm{MSH}$ $(100 \mathrm{nM})$ for $48 \mathrm{~h}$. We prepared the total cell lysates, as previously described [62,63]. Cells $\left(1 \times 10^{6}\right.$ cells $\left./ \mathrm{mL}\right)$ were washed with cold PBS and lysed with buffer $(20 \mathrm{mM}$ Tris- $\mathrm{HCl}, \mathrm{pH}$ 7.4, 2 mM EDTA, 2 mM EGTA, $50 \mathrm{mM}$ glycerol phosphate, $1 \mathrm{mM} \mathrm{DTT,} 2 \mu \mathrm{g} / \mathrm{mL}$ aprotinin, 
$2 \mu \mathrm{g} / \mathrm{mL}$ leupeptin, $1 \mu \mathrm{g} / \mathrm{mL}$ pepstatin, $50 \mu \mathrm{M}$ PMSF, $1 \mathrm{mM}$ benzamide, $2 \%$ Triton X-100, $10 \%$ glycerol, $0.1 \mathrm{mM}$ sodium vanadate, $1.6 \mathrm{mM}$ pervanadate, and $20 \mathrm{mM} \mathrm{NaF}$ ). Total cell lysates were clarified by centrifugation at $12,000 \mathrm{rpm}$ for $5 \mathrm{~min}$ at $4{ }^{\circ} \mathrm{C}$, and stored at $-20^{\circ} \mathrm{C}$ until used.

\subsection{Western Blotting Analysis}

Proteins were quantified and separated using SDS-polyacrylamide gel electrophoresis. SDS gel proteins were transferred to polyvinylidene fluoride membranes. The membranes were blocked using $5 \%$ bovine serum albumin (BSA) in $0.1 \%$ TBST (Tris-base, $\mathrm{NaCl}$ and $0.1 \%$ Tween 20 ) at room temperature for $1 \mathrm{~h}$, followed by the incubation with specific primary antibodies for at least $1 \mathrm{~h}$ at room temperature. After primary antibody incubation, the membranes were washed with $0.1 \%$ TBST 3 times for 10 min each. The membrane was incubated with HRP-linked secondary antibodies in 3\% BSA solution for at least $1 \mathrm{~h}$ at room temperature and washed with $0.1 \%$ TBST 3 times for $10 \mathrm{~min}$ each. Phosphorylated and total forms of tyrosinase, MITF, PKA, CREB, ERK, JNK, p38, and $\beta$-actin were used. To detect target proteins, we used specific antibodies and protein bands were visualized using enhanced chemiluminescence reagents. Western blotting analysis was conducted, as previously described $[60,63]$.

\subsection{Luciferase Assay}

B16F10 cells $\left(1 \times 10^{5}\right.$ cells/well $)$ were seeded for $24 \mathrm{~h}$ into a 12-well plate prior to transfection with plasmids $(0.8 \mu \mathrm{g} / \mathrm{mL}$ per well), encoding a luciferase gene under a CREB promoter and $\beta$-galacosidase as a control by the lipofectamine method, as previously reported [32]. After $24 \mathrm{~h}$ of stabilization, the transfected cells were treated with TSA $(12.5-25 \mu \mathrm{M})$ or arbutin $(1 \mathrm{mM})$ concomitantly with $\alpha$-MSH $(100 \mathrm{nM})$ for the next $24 \mathrm{~h}$. Luciferase activity was assessed using the Luciferase Assay System (Promega, Madison, WI, USA), as previously reported $[64,65]$.

\subsection{Enzyme-Linked Immunosorbent Assay (ELISA)}

B1F10 cells $\left(4 \times 10^{5}\right.$ cells/well) were seeded into a 6-well plate and incubated for $24 \mathrm{~h}$. The culture media was changed into new fresh media containing TSA $(12.5-25 \mu \mathrm{M})$ and arbutin $(1 \mathrm{mM})$ and incubated for $24 \mathrm{~h}$. The supernatant of the media was collected from each well, and cyclic AMP was measured with an ELISA assay kit (Abcam, Cambridge, UK), following the manufacturer's instructions.

\subsection{Statistical Analysis}

All data of the experiment are presented as a mean \pm standard deviation (SD) of at least three replicates of each experiment. Experimental and control groups were compared by Mann-Whitney test. A $p$ value $<0.05$ was considered statistically significant $\left({ }^{*} p<0.05,{ }^{* *} p<0.01\right)$. The SPSS program (SPSS Inc., Chicago, IL, USA) was used for statistical analysis.

\section{Conclusions}

The results of this study showed that TSA suppresses melanin formation control and improves whitening effects in test premises by inhibiting the cAMP signaling pathway, which is managed by balancing between adenylyl cyclase (AC) and cAMP phosphodiesterases (cAMP PDEs) instead of via MAPK signaling and the tyrosinase inhibitory activity level. These results suggest that TSA can be developed as a cosmeceutical material with anti-melanogenic activity, which can be used for skin improvement or as an anti-skin hyperpigmentation agent to treat dyschromia and lentigo, conditions mostly caused by UV irradiation. The exact mechanism of how TSA can increase the cAMP level will be further studied in terms of the activation of AC or the inhibition of cAMP PDEs. Additionally, since it was reported that some plant-derived compounds with anti-melanogenic activities 
have the possibility to induce cellular senescence [66,67], whether TSA can also cause this phenomenon will likewise be examined.

Supplementary Materials: The following are available online at https:/ /www.mdpi.com/article/10 .3390/ijms22147453/s1, Figure S1: Anti-mutagenic activity of TSA.

Author Contributions: H.Y.L., E.K., S.H.P., G.-H.S. and J.Y.C. designed the experiments. H.Y.L., E.K., S.H.P., K.H.H., S.R.K., D.K. and Y.D.H. performed the laboratory assays. H.Y.L., E.K., S.H.P., Y.-J.J., G.-H.S. and J.Y.C. analyzed the data. H.Y.L., E.K., S.H.P., G.-H.S. and J.Y.C., wrote the manuscript. All authors have read and agreed to the submitted version of the manuscript.

Funding: This research was supported by the Basic Science Research Program through the National Research Foundation of Korea (NRF), funded by the Ministry of Science and ICT (2017R1A6A1A03015642) and by AmorePacific Co. (Yongin, Korea). APC was funded by AmorePacific Co. (Yongin, Korea).

Institutional Review Board Statement: Not applicable.

Informed Consent Statement: Not applicable.

Data Availability Statement: The data used to support the findings of this study are available from the corresponding authors upon request.

Conflicts of Interest: The authors declare no conflict of interest.

$\begin{array}{ll}\text { Abbreviations } \\ \text { TSA } & \text { Theasinensin A } \\ \text { AP-1 } & \text { Activator protein 1 } \\ \text { Tyrp1 } & \text { Tyrosinase-related protein } 1 \\ \text { Tyrp2 } & \text { Tyrosinase-related protein } 2 \\ \text { CREB } & \text { cAMP response element binding } \\ \text { PKA } & \text { Protein kinase A } \\ \text { MITF } & \text { Microphthalmia-associated transcription factor } \\ \text { MC1R } & \text { Melanocortin 1 receptor } \\ \alpha \text {-MSH } & \alpha \text {-Melanocyte-stimulating hormone } \\ \text { NHEM } & \text { Normal human epidermal melanocytes }\end{array}$

\section{References}

1. Qomaladewi, N.P.; Kim, M.Y.; Cho, J.Y. Rottlerin Reduces cAMP/CREB-Mediated Melanogenesis via Regulation of Autophagy. Int. J. Mol. Sci. 2019, 20, 2081. [CrossRef]

2. Zhu, L.; Lu, Y.; Yu, W.G.; Zhao, X.; Lu, Y.H. Anti-photoageing and anti-melanogenesis activities of chrysin. Pharm. Biol. 2016, 54, 2692-2700. [CrossRef] [PubMed]

3. Dabrowska, A.K.; Spano, F.; Derler, S.; Adlhart, C.; Spencer, N.D.; Rossi, R.M. The relationship between skin function, barrier properties, and body-dependent factors. Skin Res. Technol. 2018, 24, 165-174. [CrossRef] [PubMed]

4. Gravitz, L. Skin. Nature 2018, 563, S83. [CrossRef] [PubMed]

5. Lee, J.O.; Kim, E.; Kim, J.H.; Hong, Y.H.; Kim, H.G.; Jeong, D.; Kim, J.; Kim, S.H.; Park, C.; Seo, D.B.; et al. Antimelanogenesis and skin-protective activities of Panax ginseng calyx ethanol extract. J. Ginseng Res. 2018, 42, 389-399. [CrossRef] [PubMed]

6. Lin, J.Y.; Fisher, D.E. Melanocyte biology and skin pigmentation. Nature 2007, 445, 843-850. [CrossRef] [PubMed]

7. Zhang, C.; Chery, S.; Lazerson, A.; Altman, N.H.; Jackson, R.; Holt, G.; Campos, M.; Schally, A.V.; Mirsaeidi, M. Anti-inflammatory effects of alpha-MSH through p-CREB expression in sarcoidosis like granuloma model. Sci. Rep. 2020, 10, 7277. [CrossRef]

8. Ravnskjaer, K.; Madiraju, A.; Montminy, M. Role of the cAMP Pathway in Glucose and Lipid Metabolism. Handb. Exp. Pharmacol. 2016, 233, 29-49. [CrossRef]

9. Ukiya, M.; Sato, D.; Kimura, H.; Hirai, Y.; Nishina, A. Tokoronin Contained in Dioscorea tokoro Makino ex Miyabe Suppressed alpha-MSH-Induced Melanogenesis in B16 Cells via Suppression of Classical MAPK Pathway Activation. Chem. Biodivers. 2020. [CrossRef]

10. Herraiz, C.; Garcia-Borron, J.C.; Jimenez-Cervantes, C.; Olivares, C. MC1R signaling. Intracellular partners and pathophysiological implications. Biochim. Biophys. Acta Mol. Basis Dis. 2017, 1863, 2448-2461. [CrossRef]

11. Cheng, M.C.; Lee, T.H.; Chu, Y.T.; Syu, L.L.; Hsu, S.J.; Cheng, C.H.; Wu, J.; Lee, C.K. Melanogenesis Inhibitors from the Rhizoma of Ligusticum Sinense in B16-F10 Melanoma Cells In Vitro and Zebrafish In Vivo. Int. J. Mol. Sci. 2018, 19, 3994. [CrossRef]

12. Haraszti, S.; Ezaldein, H.; Delost, G.R. Eruptive melanocytic nevi in a patient with Parkinson disease treated by carbidopalevodopa. JAAD Case Rep. 2019, 5, 21-23. [CrossRef] 
13. Wu, Q.Y.; Wong, Z.C.; Wang, C.; Fung, A.H.; Wong, E.O.; Chan, G.K.; Dong, T.T.; Chen, Y.; Tsim, K.W. Isoorientin derived from Gentiana veitchiorum Hemsl. flowers inhibits melanogenesis by down-regulating MITF-induced tyrosinase expression. Phytomedicine Int. J. Phytother. Phytopharm. 2019, 57, 129-136. [CrossRef]

14. Jin, J.; Nguyen, T.T.H.; Kim, C.; Kim, D. Antimelanogenesis Effects of Fungal Exopolysaccharides Prepared from Submerged Culture of Fomitopsis castanea Mycelia. J. Microbiol. Biotechnol. 2019, 29, 1204-1211. [CrossRef] [PubMed]

15. Kim, Y.; Lee, S.; Ryu, J.H.; Yoon, K.D.; Shin, S.S. Effect of Aurea Helianthus stem extract on anti-melanogenesis. Biosci. Biotechnol. Biochem. 2018, 82, 1871-1879. [CrossRef] [PubMed]

16. Hu, D.N. Methodology for evaluation of melanin content and production of pigment cells in vitro. Photochem. Photobiol. 2008, 84, 645-649. [CrossRef]

17. Lee, A.; Kim, J.Y.; Heo, J.; Cho, D.H.; Kim, H.S.; An, I.S.; An, S.; Bae, S. The Inhibition of Melanogenesis Via the PKA and ERK Signaling Pathways by Chlamydomonas reinhardtii Extract in B16F10 Melanoma Cells and Artificial Human Skin Equivalents. J. Microbiol. Biotechnol. 2018, 28, 2121-2132. [CrossRef]

18. Makbal, R.; Villareal, M.O.; Gadhi, C.; Hafidi, A.; Isoda, H. Argania Spinosa Fruit Shell Extract-Induced Melanogenesis via cAMP Signaling Pathway Activation. Int. J. Mol. Sci. 2020, 21, 2539. [CrossRef]

19. Matsumura, Y.; Ananthaswamy, H.N. Toxic effects of ultraviolet radiation on the skin. Toxicol. Appl. Pharmacol. 2004, 195, 298-308. [CrossRef] [PubMed]

20. Mun, G.-I.; Kim, S.; Choi, E.; Kim, C.S.; Lee, Y.-S. Pharmacology of natural radioprotectors. Arch. Pharmacal Res. 2018, 41, 1033-1050. [CrossRef] [PubMed]

21. Garmyn, M.; Young, A.R.; Miller, S.A. Mechanisms of and variables affecting UVR photoadaptation in human skin. Photochem. Photobiol. Sci. 2018, 17, 1932-1940. [CrossRef]

22. Choudhary, R.; Sharma, A.; Kumar, S.; Upadhyay, R.C.; Singh, S.V.; Mohanty, A. Role of alpha-melanocyte stimulating hormone (alpha-MSH) in modulating the molecular mechanism adopted by melanocytes of Bos indicus under UVR stress. Mol. Cell. Biochem. 2020, 465, 141-153. [CrossRef]

23. Reinehr, C.P.H.; Bakos, R.M. Actinic keratoses: Review of clinical, dermoscopic, and therapeutic aspects. Bras. Derm. 2019, 94, 637-657. [CrossRef]

24. Rastrelli, M.; Tropea, S.; Rossi, C.R.; Alaibac, M. Melanoma: Epidemiology, risk factors, pathogenesis, diagnosis and classification. In Vivo 2014, 28, 1005-1011.

25. Vanhaecke, T.; Papeleu, P.; Elaut, G.; Rogiers, V. Trichostatin A-like hydroxamate histone deacetylase inhibitors as therapeutic agents: Toxicological point of view. Curr. Med. Chem. 2004, 11, 1629-1643. [CrossRef] [PubMed]

26. You, W.; Steegborn, C. Structural Basis of Sirtuin 6 Inhibition by the Hydroxamate Trichostatin A: Implications for Protein Deacylase Drug Development. J. Med. Chem. 2018, 61, 10922-10928. [CrossRef] [PubMed]

27. Shankar, S.; Srivastava, R.K. Histone deacetylase inhibitors: Mechanisms and clinical significance in cancer: HDAC inhibitorinduced apoptosis. Adv. Exp. Med. Biol. 2008, 615, 261-298. [CrossRef]

28. Hou, D.X.; Masuzaki, S.; Tanigawa, S.; Hashimoto, F.; Chen, J.; Sogo, T.; Fujii, M. Oolong tea theasinensins attenuate cyclooxygenase-2 expression in lipopolysaccharide (LPS)-activated mouse macrophages: Structure-activity relationship and molecular mechanisms. J. Agric. Food Chem. 2010, 58, 12735-12743. [CrossRef] [PubMed]

29. Hisanaga, A.; Ishida, H.; Sakao, K.; Sogo, T.; Kumamoto, T.; Hashimoto, F.; Hou, D.X. Anti-inflammatory activity and molecular mechanism of Oolong tea theasinensin. Food Funct. 2014, 5, 1891-1897. [CrossRef] [PubMed]

30. Kumar, C.M.; Sathisha, U.V.; Dharmesh, S.; Rao, A.G.; Singh, S.A. Interaction of sesamol (3,4-methylenedioxyphenol) with tyrosinase and its effect on melanin synthesis. Biochimie 2011, 93, 562-569. [CrossRef] [PubMed]

31. Mendes, E.; Perry Mde, J.; Francisco, A.P. Design and discovery of mushroom tyrosinase inhibitors and their therapeutic applications. Expert Opin. Drug Discov. 2014, 9, 533-554. [CrossRef]

32. Lee, J.O.; Hwang, S.H.; Shen, T.; Kim, J.H.; You, L.; Hu, W.; Cho, J.Y. Enhancement of skin barrier and hydration-related molecules by protopanaxatriol in human keratinocytes. J. Ginseng Res. 2021, 45, 354-360. [CrossRef]

33. Saba, E.; Kim, S.H.; Lee, Y.Y.; Park, C.K.; Oh, J.W.; Kim, T.H.; Kim, H.K.; Roh, S.S.; Rhee, M.H. Korean Red Ginseng extract ameliorates melanogenesis in humans and induces antiphotoaging effects in ultraviolet B-irradiated hairless mice. J. Ginseng Res. 2020, 44, 496-505. [CrossRef] [PubMed]

34. Schioth, H.B.; Mutulis, F.; Muceniece, R.; Prusis, P.; Wikberg, J.E. Discovery of novel melanocortin4 receptor selective MSH analogues. Br. J. Pharmacol. 1998, 124, 75-82. [CrossRef]

35. Pillaiyar, T.; Manickam, M.; Namasivayam, V. Skin whitening agents: Medicinal chemistry perspective of tyrosinase inhibitors. J. Enzym. Inhib. Med. Chem. 2017, 32, 403-425. [CrossRef] [PubMed]

36. Lee, J.Y.; Lee, J.; Min, D.; Kim, J.; Kim, H.J.; No, K.T. Tyrosinase-Targeting Gallacetophenone Inhibits Melanogenesis in Melanocytes and Human Skin-Equivalents. Int. J. Mol. Sci. 2020, 21, 3144. [CrossRef] [PubMed]

37. Pearson, G.; Robinson, F.; Beers Gibson, T.; Xu, B.E.; Karandikar, M.; Berman, K.; Cobb, M.H. Mitogen-activated protein (MAP) kinase pathways: Regulation and physiological functions. Endocr. Rev. 2001, 22, 153-183. [CrossRef] [PubMed]

38. D'Mello, S.A.; Finlay, G.J.; Baguley, B.C.; Askarian-Amiri, M.E. Signaling Pathways in Melanogenesis. Int. J. Mol. Sci. 2016, 17, 1144. [CrossRef]

39. Ahn, J.H.; Jin, S.H.; Kang, H.Y. LPS induces melanogenesis through p38 MAPK activation in human melanocytes. Arch. Dermatol. Res. 2008, 300, 325-329. [CrossRef] 
40. Hwang, Y.S.; Oh, S.W.; Park, S.-H.; Lee, J.; Yoo, J.A.; Kwon, K.; Park, S.J.; Kim, J.; Yu, E.; Cho, J.Y. Melanogenic Effects of Maclurin Are Mediated through the Activation of cAMP/PKA/CREB and p38 MAPK/CREB Signaling Pathways. Oxidative Med. Cell. Longev. 2019, 2019, 9827519. [CrossRef]

41. Kang, M.; Park, S.-H.; Oh, S.W.; Lee, S.E.; Yoo, J.A.; Nho, Y.H.; Lee, S.; Han, B.S.; Cho, J.Y.; Lee, J. Anti-melanogenic effects of resorcinol are mediated by suppression of cAMP signaling and activation of p38 MAPK signaling. Biosci. Biotechnol. Biochem. 2018, 82, 1188-1196. [CrossRef] [PubMed]

42. Wellbrock, C.; Arozarena, I. Microphthalmia-associated transcription factor in melanoma development and MAP-kinase pathway targeted therapy. Pigment Cell Melanoma Res. 2015, 28, 390-406. [CrossRef] [PubMed]

43. Bellei, B.; Maresca, V.; Flori, E.; Pitisci, A.; Larue, L.; Picardo, M. p38 regulates pigmentation via proteasomal degradation of tyrosinase. J. Biol. Chem. 2010, 285, 7288-7299. [CrossRef] [PubMed]

44. Alam, M.B.; Bajpai, V.K.; Lee, J.; Zhao, P.; Byeon, J.-H.; Ra, J.-S.; Majumder, R.; Lee, J.S.; Yoon, J.-I.; Rather, I.A. Inhibition of melanogenesis by jineol from Scolopendra subspinipes mutilans via MAP-Kinase mediated MITF downregulation and the proteasomal degradation of tyrosinase. Sci. Rep. 2017, 7, 45858. [CrossRef] [PubMed]

45. Huang, H.-C.; Liao, C.-C.; Peng, C.-C.; Lim, J.-M.; Siao, J.-H.; Wei, C.-M.; Chen, C.-C.; Wu, C.-S.; Chang, T.-M. Dihydromyricetin from Ampelopsis grossedentata inhibits melanogenesis through down-regulation of MAPK, PKA and PKC signaling pathways. Chem. Biol. Interact. 2016, 258, 166-174. [CrossRef]

46. Lee, S.E.; Park, S.-H.; Oh, S.W.; Yoo, J.A.; Kwon, K.; Park, S.J.; Kim, J.; Lee, H.S.; Cho, J.Y.; Lee, J. Beauvericin inhibits melanogenesis by regulating cAMP/PKA/CREB and LXR- $\alpha /$ p38 MAPK-mediated pathways. Sci. Rep. 2018, 8, 1-12. [CrossRef]

47. Kim, M.-O.; Park, S.J.; Park, S.-H.; Oh, S.W.; Lee, S.E.; Yoo, J.A.; Kwon, K.; Kim, J.; Kim, M.H.; Cho, J.Y. Ethanolic extract of Melia azedarach L. induces melanogenesis through the cAMP-PKA-CREB signaling pathway. Mol. Cell. Toxicol. 2019, 15, 75-83. [CrossRef]

48. Valverde, P.; Healy, E.; Jackson, I.; Rees, J.L.; Thody, A.J. Variants of the melanocyte-stimulating hormone receptor gene are associated with red hair and fair skin in humans. Nat. Genet. 1995, 11, 328-330. [CrossRef]

49. Ozdeslik, R.N.; Olinski, L.E.; Trieu, M.M.; Oprian, D.D.; Oancea, E. Human nonvisual opsin 3 regulates pigmentation of epidermal melanocytes through functional interaction with melanocortin 1 receptor. Proc. Natl. Acad. Sci. USA 2019, 116, 11508-11517. [CrossRef]

50. Seo, G.Y.; Ha, Y.; Park, A.H.; Kwon, O.W.; Kim, Y.J. Leathesia difformis Extract Inhibits $\alpha$-MSH-Induced Melanogenesis in B16F10 Cells via Down-Regulation of CREB Signaling Pathway. Int. J. Mol. Sci. 2019, 20, 536. [CrossRef]

51. Wu, P.-Y.; You, Y.-J.; Liu, Y.-J.; Hou, C.-W.; Wu, C.-S.; Wen, K.-C.; Lin, C.-Y.; Chiang, H.-M. Sesamol inhibited melanogenesis by regulating melanin-related signal transduction in B16F10 cells. Int. J. Mol. Sci. 2018, 19, 1108. [CrossRef]

52. Chung, Y.C.; Kim, M.-J.; Kang, E.Y.; Kim, Y.B.; Kim, B.S.; Park, S.-M.; Hyun, C.-G. Anti-Melanogenic Effects of Hydroxyectoine via MITF Inhibition by JNK, p38, and AKT Pathways in B16F10 Melanoma Cells. Nat. Prod. Commun. 2019, 14, 1934578X19858523. [CrossRef]

53. Kuo, Y.-H.; Chen, C.-C.; Wu, P.-Y.; Wu, C.-S.; Sung, P.-J.; Lin, C.-Y.; Chiang, H.-M. N-(4-methoxyphenyl) caffeamide-induced melanogenesis inhibition mechanisms. BMC Complementary Altern. Med. 2017, 17, 1-8. [CrossRef]

54. Niu, C.; Yin, L.; Aisa, H.A. Novel furocoumarin derivatives stimulate melanogenesis in B16 melanoma cells by up-regulation of MITF and TYR family via Akt/GSK3 $\beta / \beta$-catenin signaling pathways. Int. J. Mol. Sci. 2018, 19, 746. [CrossRef]

55. Jeong, D.; Qomaladewi, N.P.; Lee, J.; Park, S.H.; Cho, J.Y. The Role of Autophagy in Skin Fibroblasts, Keratinocytes, Melanocytes, and Epidermal Stem Cells. J. Investig. Dermatol. 2020, 140, 1691-1697. [CrossRef]

56. Kindl, G.H.; D’Orazio, J.A. Pharmacologic manipulation of skin pigmentation. Pigment Cell Melanoma Res. 2021. [CrossRef]

57. Gado, F.; Digiacomo, M.; Salsano, J.E.; Macchia, M.; Manera, C. Phenolic Compounds in Prevention and Treatment of Skin Cancers: A review. Curr. Med. Chem. 2021. [CrossRef]

58. Dybdahl, M.; Selesko, D.B.; Mikkelsen, U.R. Safety evaluation of whey derived beta-lactoglobulin, Lacprodan(R) BLG. Toxicol. Rep. 2021, 8, 617-626. [CrossRef]

59. Lorz, L.R.; Yoo, B.C.; Kim, M.Y.; Cho, J.Y. Anti-Wrinkling and Anti-Melanogenic Effect of Pradosia mutisii Methanol Extract. Int J. Mol. Sci. 2019, 20, 1043. [CrossRef] [PubMed]

60. Lim, H.Y.; Jeong, D.; Park, S.H.; Shin, K.K.; Hong, Y.H.; Kim, E.; Yu, Y.G.; Kim, T.R.; Kim, H.; Lee, J.; et al. Antiwrinkle and Antimelanogenesis Effects of Tyndallized Lactobacillus acidophilus KCCM12625P. Int. J. Mol. Sci. 2020, 21, 1620. [CrossRef] [PubMed]

61. Park, S.H.; Yi, Y.-S.; Kim, M.-Y.; Cho, J.Y. Antioxidative and antimelanogenesis effect of momordica charantia methanol extract. Evid. -Based Complementary Altern. Med. 2019, 2019, 5091534. [CrossRef]

62. Shin, K.K.; Park, J.G.; Hong, Y.H.; Aziz, N.; Park, S.H.; Kim, S.; Kim, E.; Cho, J.Y. Anti-Inflammatory Effects of Licania macrocarpa Cuatrec Methanol Extract Target Src-and TAK1-Mediated Pathways. Evid. Based Complementary Altern. Med. 2019, $2019,4873870$. [CrossRef]

63. Kim, H.G.; Choi, S.; Lee, J.; Hong, Y.H.; Jeong, D.; Yoon, K.; Yoon, D.H.; Sung, G.-H.; Lee, S.; Hong, S. Src is a prime target inhibited by celtis choseniana methanol extract in its anti-inflammatory action. Evid. Based Complementary Altern. Med. 2018, 2018, 3909038. [CrossRef] [PubMed]

64. Cha, H.J. Cnidium officinale Makino Extracts Inhibit $\alpha$-MSH-induced Melanogenesis in B16F10 Mouse Melanoma Cells. Asian J. Beauty Cosmetol. 2018, 16, 122-130. [CrossRef] 
65. Qomaladewi, N.P.; Aziz, N.; Kim, M.-Y.; Cho, J.Y. Piper cubeba L. methanol extract has anti-inflammatory activity targeting Src/Syk via NF-B inhibition. Evid. Based Complementary Altern. Med. 2019, 2019, 1548125. [CrossRef] [PubMed]

66. Yang, D.; Xu, X.; Wang, X.; Feng, W.; Shen, X.; Zhang, J.; Liu, H.; Xie, C.; Wu, Q.; Miao, X.; et al. beta-elemene promotes the senescence of glioma cells through regulating YAP-CDK6 signaling. Am. J. Cancer Res. 2021, 11, 370-388. [PubMed]

67. Nanni, V.; Canuti, L.; Gismondi, A.; Canini, A. Hydroalcoholic extract of Spartium junceum L. flowers inhibits growth and melanogenesis in B16-F10 cells by inducing senescence. Phytomedicine Int. J. Phytother. Phytopharm. 2018, 46, 1-10. [CrossRef] 